\title{
South African universities are squeezed by still more cuts
}

London

South African universities seem more than ever at loggerheads with the government after the events of the past month, in particular the announcement that government payments to universities will be reduced by between a further 8 and 12 per cent in the academic year now beginning.

This decision followed by only two weeks the publication of a report by the Committee of University Principals (CUP) pleading, among other things, that the funds generated by the subsidy formula should be passed on in full to the universities. The proposed cuts are distinct from the threatened discriminatory cuts of the subsidies to universities which have displeased the government.

The committee responsible for the CUP report, under Professor J.P. de Lange (who resigned in 1986 as rector of the Rand Afrikaans University), is likely also to be disappointed in its plea that university salaries should be urgently increased. Its report also asks for a rationalization of the university system to cope with dwindling resources, the creation of a single ministry for tertiary education and the study of new ways of identifying students likely to benefit from tertiary education.

All universities will be hurt by the reduction of subsidies, which are determined by a complicated formula for calculating an institution's 'ideal' need, based on graduate and undergraduate student numbers (differently weighted), success rates and research output. Universities are expected to pay a proportion of this amount from fees paid by students and from endowment income. The balance of the universities' budget is paid by the state, which has cut its contribution by 17 per cent per annum over the past 3 years. Now the government has announced that in 1988 this reduction wil be increased to between 25 and 29 per cent .

Apparently reconciled to continuing privation, the report recommends that CUP should put forward guidelines for rationalization of the 21 universities. It suggests a system of accreditation to determine which departments have the right to accept graduate students rather than one in which whole institutions will be restricted to undergraduate teaching.

Academic salaries are another bone of contention. The CUP report says that, in real terms, professors' salaries have declined by almost 50 per cent since 1971 , and are now the same as those of lecturers in 1981. And while inflation is now running at 15 per cent a year, academic salaries have been neglected except in medical faculties.

Despite the difficulties, the South
African university system appears to keep growing. There was an almost threefold increase of staff numbers between 1965 and 1985 while, during the same period, student numbers increased from 59,000 to 215,000 . Overall, university students amounted to 7.7 per 1,000 total population in 1985 , compared with 7.5 per 1,000 in Britain. For the white population, the proportion was 29.2 per 1,000 , on a par with France, with the highest per capita student population in Europe. The CUP report notes the increasing participation of women, but a sharp decrease in the proportions of students reading engineering, science and medicine.

The CUP also records a rapid growth of non-white student numbers in all tertiary education institutions. Whereas white students accounted for 67 per cent of the total in 1979 , the proportion will have fallen to 35 per cent by the end of this decade, and may be only 12 per cent by the

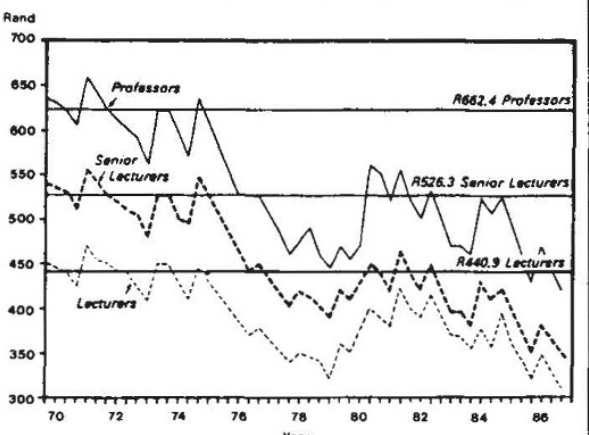

Real earnings (1970 prices) of professors and lecturers.

end of the century. Because of the decline of white births in the early $1970 \mathrm{~s}$, the admission of black students to the ten universities under the "white" Department of Education and Culture will increase, especially at the four universities with open admissions policies, so that the supervision of tertiary education by five ministries is more ludicrous than ever. The government has sought to control the growth of black numbers at the Englishlanguage universities by pegging the numbers qualifying for the state subsidy at 1986 levels.

On admission requirements, the CUP committee says that a candidate's potential as well as scholastic performance should be a consideration in the award of a university place. It also asks for an improvement of standards of secondary schooling and, cautiously, recommends a unified examining body at the secondary level. Recognizing that this proposal is unlikely to be acceptable to the government, the committee advocates bridging courses to counter inequities in primary and secondary education. Michael Cherry

\section{French medics to go on-line}

Paris

MEDLINE, the world's largest bibliographical database, is now integrated with the French national videotext network, Minitel. This will mean that MEDLINE's 4.7 million references can be consulted through any of the 3 million conventional Minitel terminals in France.

Potential users of MEDLINE will have to subscribe, but 'kiosk' access - the highly successful 'pay-as-you-go' charge system developed by the French telecommunications service for Minitel users - will soon be available. As users will also be able to order a photocopy of a desired article or its abstract without going to a terminal at a major library, it is hoped that the new service will encourage medical practitioners to keep up with current research.

The new MEDLINE service was launched in Paris last month at a two-day conference organized by INSERM, the national institute of health and medical research. The conference concluded a series of 12 national 'mini-symposia' exploring existing and possible future links between basic and clinical biomedical research.

Since 1985, INSERM has organized annual national research seminars around a specific topic. The theme of clinical research was felt to be appropriate this year, not least because the application of fundamental research in molecular biology and immunology has been so obviously important in recent research on AIDS (acquired immune deficiency syndrome) and other infectious diseases. But French scientists, like many of their western colleagues, also have to justify their demands on the state purse.

Co-financed by the Ministry for Research and Higher Education and the Health Ministry, INSERM spends about 25 per cent of its $£ 100$ million budget on clinical research. But almost half of its 249 research units are in hospitals and 32 per cent of full-time researchers are medical doctors. INSERM research units have benefitted from several national research campaigns and so have been less affected by government reticence to fund basic research.

INSERM nevertheless feels it has to be seen to carry out applied research. When she took over the Health Ministry in 1986, Michèle Barzach asked INSERM for specific research initiatives on the major fatal diseases in France. "There is no question of undermining basic research . . . it is indispensable", said Barzach at the conference in Paris. But she is "counting on INSERM" to come up with research that has some direct clinical applications.

Peter Coles 